\title{
Praktik Jurnalisme Lingkungan di Media Daring: Analisis Isi Isu Reklamasi Teluk Jakarta di Media Kompas.com
}

\author{
Rhoma DY. Reynaldi \\ rhoma.dhino15@mhs.uinjkt.ac.id \\ Bintan Humeira \\ bintan.humeira@uinjkt.ac.id
}

\begin{abstract}
ABSTRAK
Media memiliki pengaruh penting dalam meningkatkan literasi masyarakat tentang kesadaran lingkungan. Namun, pemberitaan tentang lingkungan kurang mendapatkan prioritas dibanding berita politik dan ekonomi, dan bahkan isu lingkungan lebih banyak dibingkai sebagai komoditas politik daripada literasi lingkungan.

Riset ini bertujuan untuk menjelaskan bagaimana isu reklamasi pantai utara Jakarta tampil dalam media daring Kompas.com berdasarkan kategorisasi yang dominan dan fungsi pemberitaan dalam perspektif jurnalisme lingkungan hidup. Untuk itu riset ini menggunakan perspektif teori jurnalisme lingkungan dan metode analisis isi kuantitatif .

Hasi riset ini menunjukkan bahwa pemberitaan reklamasi pantai Jakarta selama tahun 2016 lebih banyak ditampilkan dalam kategorisasi isu hukum dan peraturan perundangan, dan lebih banyak menggunakan fungsi informasi sebagai fungsi pemberitaan dominan. Dengan demikian riset ini menunjukkan media lebih banyak menyajikan isu lingkungan dari perspektif hukum dalam konteks politik daripada literasi tentang persoalan lingkungan. Hal ini terjadi karena tahun 2016 merupakan tahun politik menjelang Pilkada DKI Jakarta di tahun 2017 sehingga isu lingkungan lebih ditampilkan sebagai komoditas politik, minim dalam penerapan prinsip jurnalisme lingkungan.
\end{abstract}

Kata kunci :Jurnalisme Lingkungan, Reklamasi, Media, Analisis Isi.

Permalink/DOI: http://doi.org/10.15408/jsj.v3i2.22984

\section{A. Pendahuluan}

Media massa memiliki peran yang penting dalam kehidupan sosial masyarakat dan berbangsa. Hal ini terjadi karena media massa memiliki kekuatan untuk membentuk dan menggiring opini masyarakat melalui pemberitaannya. ${ }^{1}$ Dengan demikian, dengan sumber daya yang dimiliki, media massa mempunyai kuasa untuk membingkai

1 Bernays, Propaganda, (Brooklyn: NY Ig Publishing, 2005), h. 150 peristiwa sosial tertentu tampil menarik perhatian publik sekaligus meningkatkan pengetahuan dan pemahaman khalayak tentang isu tertentu.

Wilbur Schramm mengatakan bahwa media massa adalah pengamat, forum, dan guru bagi publik. ${ }^{2}$ Setiap hari media massa atau pers melaporkan dan mengulas beragam kejadian dan peristiwa. Abrar

2 F. Rachmadi, Perbandingan Sistem Pers; Analisis Deskriptif Sistem Pers di Berbagai Negara, (Jakarta: Penerbit Gramedia, 1990), h. 3. 
mengatakan bahwa media tidak sekedar menyediakan sejumlah fakta atas peristiwa namun juga menafsirkan peristiwa ke dalam bahasa publik agar publik berpikir dan bertindak atas dasar tafsir tersebut. ${ }^{3}$

Salah satu isu yang diulas dan diangkat oleh media massa adalah isu lingkungan hidup. Melalui media, publik membutuhkan bantuan untuk memahami dan menyikapi lingkungan sebagai ruang kehidupan mereka secara tepat.

Kekhawatiran akan semakin memburuk-nya keadaan lingkungan hidup dan rendahnya kepedulian masyarakat terhadap lingkungan membuat sebagian pewarta berita menginisiasi lahirnya jurnalisme lingkungan hidup.

Media massa memiliki tanggung jawab sosial untuk menyajikan informasi yang mendorong publik melakukan tindakan yang berorientasi pada kelestarian lingkungan hidup. Dalam hal ini, media massa bertindak sebagai agen yang melalui pemberitaannya dapat memberikan manusia pengetahuan dan tuntunan cara hidup berdampingan dengan alam dan lingkungan.

Selain melakukan edukasi, media massa juga bertanggung jawab untuk melakukan supervisi atas berbagai akivitas dan kebijakan publik yang bisa berdampak buruk pada kerusakan lingkungan hidup. Namun demikian, penyajian informasi yang kurang tepat, cenderung memihak pada kepentingan kelompok tertentu dan mengabaikan kelompok lainnya dapat menimbulkan konflik antar-pihak, missal antara pengusaha, pemerintah, dan masyarakat.

Salah satu kegiatan kerusakan lingkungan yang menjadi perhatian media di Indonesia adalah rusaknya ekosistem dan biota laut akibat reklamasi pantai yang dilakukan secara serampangan. Salah satunya adalah proyek reklamasi Teluk Jakarta yang menjadi perhatian media selama tahun 2016.

Secara teknis kegiatan reklamasi ini dilakukan dengan cara menguruk atau

3 Ana Nadhya Abrar, Analisis Pers: Teori dan Praktik, (Yogyakarta: Penerbit Cahaya Atma Pustaka, 2011), h.39. menimbun kawasan perairan dengan pasir dan tanah. Proses ini akan berdampak negatif pada keberlangsungan ekosistem pesisir pantai. Tidak hanya itu, reklamasi akan menganggu biota laut dan berdampak pada hilangnya sumber mata pencaharian nelayan karena hasil tangkapan berkurang. Dengan kata lain, sudut pandang yang mengusung pertumbuhan ekonomi dengan perluasan wilayah daratan ke wilayah laut, justru menyebabkan kerugian ekonomi pada kelompok masyarakat lainnya. Ini yang menjadi tarik menarik wacana reklamasi dengan ragam pro dan kontra.

Maraknya kemunculan isu reklamasi pantai Jakarta, khususnya di tahun 2016 yang sarat dengan nuansa politik menjelang pilkad DKI, tentu menjadi ruang menarik bagi liputan media. Untuk itu, riset ini bermaksud untuk melihat bagaimana media menyajikan konten pemberitaan tentang isu reklamasi pantai Jakarta selama 2016, apakah media tetap menggunakan prinsip jurnalisme lingkungan yang berpihak pada peningkatan literasi dan partisipasi publik terhadap persoalan lingkungan hidup mereka, atau sebaliknya abai dalam bertindak sebagai agen sosial yang berperan meningkatkan pengetahuan dan kesadaran masyarakat tentang lingkungan hidup. Selain itu, perlu juga melihat peran media menjalani fungsinya, apakah lebih dominan dalam fungsi informasi atau juga berperan sebagai pengawas kebijakan pemerintah atau pemangku kepentingan terkait dengan persoalan lingkungan.

\section{B. Landasan Teori}

Dalam dunia jurnalistik dikenal banyak sekali varian, misalnya jurnalistik advokasi, jurnalisme perang, jurnalisme damai, jurnalisme bencana, dan jurnalisme lingkungan hidup. Jurnalistik lingkungan hidup adalah cara dan kerangka kerja dalam liputan jurnalistik yang menunjukkan keberpihakannya pada keberlanjutan alam dan lingkungan hidup. ${ }^{4}$ Artinya orientasi pemberitaan yang dilakukan oleh jurnalisme

\footnotetext{
4 Ana Nadhya Abrar, Mengenal Jurnalisme Lingkungan
} Hidup, h. 9. 
lingkungan adalah pemeliharaan lingkungan hidup saat ini. Sehingga di kemudian hari, alam dan lingkungan bisa diwariskan pada anak-cucu generasi berikutnya dalam keadaan dan kondisi yang baik dan sama .

Tidak hanya itu, jurnalisme lingkungan hidup mendedikasikan dirinya untuk menyampaikan suara publik tentang lingkungan, berpartisipasi dalam kebijakan yang menyangkut lingkungan, dan menyajikan data yang dapat digunakan untuk membuat keputusan tentang persoalan lingkungan.

Bahan baku yang digunakan dalam pemberitaannya adalah realitas dan fakta lingkungan yang ada di lapangan. Bahan baku tersebut berupa pencemaran lingkungan, polusi baik di darat, udara, maupun air, hingga persoalan kesehatan masyarakat sebagai dampak dari pencemaran yang terjadi. Sebagaimana disinggung oleh Atmakusumah, bahwa realitas yang dijadikan bahan baku dalam pemberitaan lingkungan tidak hanya berhenti pada peristiwa dan kejadian saja, melainkan juga melibatkan aspek ekonomi, politik, dan sosial. Inilah pembeda antara isu lingkungan hidup dan isu lainnya, yakni kompleksitas isu. ${ }^{5}$

Orientasi keberpihakan seorang jurnalis dalam meliput isu lingkungan harusnya pada lingkungan hidup itu sendiri, termasuk pada aspek manusia sebagai bagian dari alam yang kehidupannya bergantung pada lingkungannya. Dalam pemberitaannya, jurnalis sebaiknya memasukkan solusi yang menyeluruh dan tuntas ke dalam pemberitaannya. Solusi ini bisa mengaitkan hubungan antara aspek ekonomi, ekologi, dan sosial. Oleh sebab itu media massa merupakan saluran yang cocok untuk memuat berita lingkungan hidup, dimana media massa dapat memberikan kesempatan

\footnotetext{
5 Atmakusumah, Maskun Iskandar, dan Warief Djajanto Basoeri, ed., Mengangkat Masalah Lingkungan ke Media Massa, (Jakarta: Penerbit Yayasan Pustaka Obor Indonesia, 1996), h. 38.

${ }^{6}$ Ana Nadhya Abrar, Mengenal Jurnalisme Lingkungan Hidup, h. 6.

${ }^{7}$ Ana Nadhya Abrar, Mengenal Jurnalisme Lingkungan Hidup, h. 66
}

kepada pembacanya untuk mengembangkan daya analisisnya. ${ }^{6}$

Sejalan dengan pendapat Soemadi Wonohito, Pemimpin Redaksi Harian Kedaulatan Rakyat, bahwa media massa mampu menumbuhkan kesadaran terkait pentingnya lingkungan yang baik lagi sehat. ${ }^{7} \mathrm{Al}$ Gore juga mengatakan hal senada bahwa media massa memiliki tanggung jawab untuk informasi yang mendidik, menjelaskan kepada kita mengapa sebuah peristiwa bisa terjadi dan apa dampaknya untuk kita hari ini dan yang akan datang. Bukan hanya melaporkan saja apa yang sedang atau telah terjadi ${ }^{8}$.

Informasi yang diangkat dari fakta dan realitas lapangan harus tepat dan akurat serta mengedukasi publik. Artinya media massa tidak sekadar menyampaikan informasi tetapi juga menumbuhkan kesadaran publik tentang lingkungannya. ${ }^{9}$

Fungsi mediasi juga diemban dalam pemberitaan lingkungan hidup. Pers tidak hanya menyajikan pendapat dari salah satu pihak saja, namun perlu mengakomodasi pendapat dari pihak-pihak yang berkaitan. Misalnya, pendapat dari pemerintah, perusahaan pengembang, dan Lembaga Swadaya Masyarakat (LSM) dalam menyikapi kebijakan lingkungan. $\mathrm{R}$. Gregory juga menyinggung fungsi ini dengan menyatakan :

... "the news media help develop the public's perception of health or environmental risk by facilitating a two-way conversation between technical expert and the public and from the public to the scientist and government or industry decision makers. "I0

Pemberitaan lingkungan yang sering mengandung konflik dengan pihak-pihak tertentu yang terkait dengan kegiatan eksplorasi dan eksploitasi lingkungan membuat fungsi mediasi menjadi penting. Salah satu bentuk proses mediasi media

\footnotetext{
${ }^{8}$ Lisa Rademakers, $A$ Theses of Examining The Handbooks On Enviromental Journalism: A Qualitative Document Analysis and Response to The Literature, h.8.

9 Albert L. Hester, dan Wai Lan J.To., Pedoman Untuk Wartawan, (Jakarta: Penerbit Yayasan Pustaka Obor Indonesia, 1997), h. 121.

${ }^{10}$ R .Gregory, Risky Business: Communicating Issues of Science, Risk, and Public Policy, (New York: Greenwood Press. 1991), h. 2.
} 
adalah memperhatikan dan merujuk pada pendapat atau pandangan akademisi karena pada dasarnya isu lingkungan hidup selalu memiliki tempat khusus dalam kajian-kajian saintifik. Sebagaimana yang ditegaskan oleh Hannigan yang mengatakan bahwa kajian tentang lingkungan berasal dari penelitian saintifik. $^{11}$

Fungsi mediasi dilakukan untuk meminimalisasi terjadinya konflik. Jika pun konflik sudah terjadi, mediasi berfungsi sebagai jembatan antar berbagai pihak yang berkepentingan. Lisa Rademakers bernada sama dengan mengungkapkan, ... "environmental journalism has been a complex beat, encompassing more than just the environment often, politics, economic, and social issues play a part." 12 Dus, persoalan lingkungan butuh banyak suara untuk mencapai satu kebijakan yang bisa meminimalisasi terjadinya dampak buruk. Mediasi menjadi jembatan untuk menghadapi ini.

Media massa juga, yang selalu disebut sebagai watchdog oleh berbagai literatur, dituntut untuk selalu bersuara terhadap ketidakadilan. Bukan malah menjadi lapdog bagi kekuasaan. Fungsi pengawasan atau supervisi menjadi sangat penting dalam masalah lingkungan. Media massa harus bersuara lantang tatkala melihat lingkungan menjadi terancam karena ulah manusia yang hendak mengeksploitasinya demi meraup keuntungan pribadi sambil meninggalkan dampak buruk bagi alam dan masyarakat sekitar. Media massa memberitakan kepada publik dengan informasi yang akurat disertai dampak dan bahaya akan kerusakan lingkungannya. Dengan adanya pemberitaan tersebut, diharapkan para pengambil kebijakan mampu menyelesaikan masalah lingkungan sebelum terjadi bencana lingkungan. Pada poin ini media massa melakukan tugasnya untuk mengontrol dan memberi kritik kepada pemangku kebijakan, perusahaan

11 A. John Hannigan, Environmental Sociology; A Social Constructionist Perspective, (London: Routledge, 1995), h. 94.

${ }^{12}$ Lisa Rademakers, $A$ Theses of Examining The Handbooks On Enviromental Journalism: A Qualitative Document Analysis and Response to The Literature, h.15. pengembang, dan masyarakat disertai dengan solusi yang harus diambil.

Dari ketiga fungsi media, fungsi supervisilah yang dekat dan identik dengan kehidupan politik sebuah negara, karena sifatnya yang mengawasi kekuasaan. Emil Salim mengatakan isu lingkungan tidak sekedar berada pada kajian ilmiah, namun sudah masuk dalam bidang politik. ${ }^{13} \mathrm{Hal}$ senada juga ditegaskan oleh Hannigan, bahwa tanpa keterlibatan media massa, isu lingkungan tidak akan masuk ke dalam diskursus publik dan mendapatkan tekanan untuk mempengaruhi politik kebijakan. ${ }^{14}$ Artinya media massa melalui fungsi supervisi memosisikan diri sebagai pressure group yang bisa memberikan input kepada sistem politik kebijakan dalam isu tertentu.

Tuntutan akan suatu kebijakan (policy demand) akan diproses dalam sistem politik. Kemudian menghasilkan kebijakan (policy output) dan dampak sebagai policy outcome, baik positif maupun negatif. Dalam pemrosesan kebijakan tersebutlah, kehadiran media massa melalui jurnalisme lingkungan hidupnya berperan penting untuk menekan pemangku kebijakan.

Pemberitaan dan kerja jurnalisme lingkungan hidup mesti melihat permasalahan secara holistik dari berbagai sudut pandang. Sehingga pemberitaan pun dituntut untuk menyusur pada akar permasalahan hingga tuntas. Pengertian jurnalisme lingkungan, jika merujuk Robert Cox, berkaitan dengan komunikasi lingkungan.

\section{Metodologi Penelitian}

Dalam penelitian ini, peneliti menggunakan paradigma positivisme karena tujuan riset ini adalah mengungkap realitas di media tentang isu lingkungan berdasarkan isu yang dominan muncul dalam periode tertentu. Untuk itu, riset ini bertujuan untuk mendeskripsikan secara

13 Emil Salim, Pembangunan Berwawasan Lingkungan, (Jakarta: LP3ES, 1986), h. ix

14 A. John Hannigan, Environmental Sociology; A Social Constructionist Perspective, (London: Routledge 1995), h. 81 
kuantitatif kategorisasi isu terkait reklamasi teluk Jakarta selama tahun 2016 berdasarkan frekuensi kemunculan kategori dominan dan isi yang merujuk pada peran media dalam praktik jurnalisme lingkungan, pada konteks isu reklamasi teluk Jakarta.

Penelitian ini menggunakan teknik analisis isi untuk melukiskan isi komunikasi yang nyata secara objektif, sistematik dan kuantitatif. ${ }^{15}$ Untuk itu, riset ini menggunakan studi dokumen tentang teks pemberitaan tentang isu reklamasi teluk Jakarta selama periode satu tahun, yaitu .tahun 2016 di media daring Kompas.com. Pemilihan Periode ini karena pada tahun tersebut isu Reklamasi Teluk Jakarta begitu menghangat hingga muncul perdebatan pro dan kontra di antara para pemangku kebijakan, pengusaha dan masyarakat luas. Unit analisi riset ini adalah satuan paragraf untuk mendeskripsikan kategori yang muncul dalam pemberitaan.

Terdapat 12 kategorisasi isu beserta definisinya yang muncul di Kompas.com tentang pemberitaan reklamasi, yaitu : 1) Isu pilkada DKI, 2) Konflik Horizontal DPRD DKI Jakarta dan Gubernur DKI Jakarta terkait kebijakan reklamasi, 3) Konflik Vertikal Gubernur DKI Jakarta dan Pemerintah Pusat terkait kebijakan reklamasi, 4) Konflik Vertikal Pemerintah dan Masyarakat, 5) Konflik Horizontal Antar-Masyarakat, 6) Tindakan melawan hukum dalam perumusan kebijakan reklamasi pantai utara Jakarta, 7) Dampak yang muncul akibat reklamasi Teluk Jakarta, 8) Mediasi akademisi terkait dampak dan kebijakan reklamasi Teluk Jakarta, 9) Peraturan perundanganundangan yang berkaitan dengan reklamasi 10Kepentingan Bisnis dan Pembangunan, Advokasi Dampak, 11) Pelestarian, dan 12)Konservasi Lingkungan

Populasi yang digunakan dalam penelitian ini sebanyak 589 artikel berita dan 6401 paragraf.

\section{Temuan dan Analisis}

\section{Fungsi Dominan Media dalam Pemberitaan Reklamasi Teluk Jakarta di Kompas.com tahun 2016.}

Dari 5962 paragraf pemberitaan tentang reklamasi teluk Jakarta selama tahun 2016, tampak bahwa sebagain besar ditulis sebagai informasi bagi publik, bukan ditujukan untuk memberikan mediasi atas pihak yang berkonflik terkait kebijakan ini atau mengmbil sebagai pengawas kebijakan (supervise). Hal ini ditunjukkan dalam tabel 1 dibawah ini :

Tabel 1. Fungsi Dominan dalam Permberitaan Reklamasi teluk Jakarta sepanjang Tahun 2016

\begin{tabular}{|c|l|c|c|}
\hline No. & \multicolumn{1}{|c|}{ Fungsi } & Persentase & Frekuensi \\
\hline .1 & Informasi & $50,59 \%$ & 3016 \\
\hline .2 & Mediasi & $32,59 \%$ & 1943 \\
\hline 3 & Supervisi & $16,82 \%$ & 1003 \\
\hline
\end{tabular}

Tabel 1 diatas menunjukkan bahwa fungsi pemberitaan tentang reklamasi teluk Jakarta secara dominan atau lebih dari 50\% hanya menjadi ruang infomasi bagi pembaca untuk mengetahui perkembangan isu. Media tidak mengambi peran mediasi lebih dominan padahal isu reklemasi teluk Jakarta membawa konflik yang tajam atara pemerintah dan masyarakat pesisir yang terdampak langsung. Ironisnya, peran media sebagai pengawas kebijakann pemeerintah atas isu reklamasi paling rendah dari fungsi lainnya. Artinya, media justru menarik diri dari peran sebagai 'anjing penjaga" (watchdog) atas kekuasaan yang berlangsung. Apalagi isu reklamasi merupakan isu yang kerap kali menimbulkan pro kontra karena sarat kepentingan dan berdampak signifikan pada kelestarian lingkungan hidup.

\footnotetext{
${ }^{15}$ Haris Sumadiria, Jurnalistik Indonesia, h. 230
} 


\section{Model Penyajian Berita dalam Pemberitaan Reklamasi Teluk Jakarta di Kompas.com tahun 2016}

Merujuk pada model penyajian berita terkait isu lingkungan, Kompas.com lebih cenderung dengan model satu sisi dari pada dua sisi atau multi sisi. Klasifikasi satu, dua, dan multi sisi ini tidak berdasarkan pada berapa banyak subyek yang dijadikan sebagai narasumber oleh Kompas.com, namun berdasarkan pada pandangan narasumber yang dimunculkan. Jika empat narasumber yang ditampilkan berpendapat sama atas satu hal, maka berita tersebut hanya menyajikan satu sisi saja .

Setelah menghitung kemunculannya, peneliti menemukan bahwa berita dengan penyajian satu sisi ternyata mendapatkan porsi lebih besar dengan nilai $78,44 \%$ atau sebanyak 462 berita, sedangkan penyajian dua sisi dan multi sisi masing-masing muncul sebanyak 18,51\% atau 109 berita dan 3,05\% atau 18 berita saja, seperti yang ditampilkan pada tabel 2 dibawah ini.

Tabel 2. Model Penyajian Berita

\begin{tabular}{|c|l|c|c|}
\hline No. & Model Penyajian Berita & Persentase & Frekuensi \\
\hline .1 & Saru Sisi & $78,44 \%$ & 462 \\
\hline .2 & Dua Sisi & $18,51 \%$ & 109 \\
\hline 3 & Multi Sisi & $3,05 \%$ & 18 \\
\hline
\end{tabular}

\section{Sebaran Narasumber dalam Pemberitaan Reklamasi Teluk Jakarta di Kompas.com tahun 2016}

Hasil analisis isi menunjukkan terdapat 11 narasumber yang dimunculkan dalam pemberitaan reklamasi. Semuanya berkaitan dengan proyek reklamasi dengan keahlian dan bidangnya masing-masing. Sebelas narasumber yang muncul selama setahun pemberitaan yaitu pemerintah (pusat dan daerah), legislator (DPR dan DPRD), Lembaga Swadaya Masyarakat, masyarakat terdampak, pengusaha atau pengembang, pakar/ahli hukum, KPK dan akademisi.
Meski kompas.com menggunakan narsumber diatas dalam pemberitaan reklamasi teluk Jakarta selama tahun 2016, namun jumlah sebaran narasumber berbeda. Ada narasumber yang sering mendapat porsi dalam pemberitaan, dan ada pihak yang jarang sekali mendapat porsi dalam pemberitaan, seperti tampak pada tabel 3 di bawah:

Tabel 3. Sebaran Narasumber

\begin{tabular}{|c|c|c|c|c|}
\hline $\begin{array}{l}\text { No. } \\
\text { Urut }\end{array}$ & No. & Kelompok & Persentase & Frekuensi \\
\hline .1 & 3 & Pemerintah Daerah & $24,05 \%$ & 184 \\
\hline .2 & 8 & $\begin{array}{l}\text { Lembaga Swadaya } \\
\text { Masyarakat }\end{array}$ & $13,59 \%$ & 104 \\
\hline .3 & 1 & Pemerintah Pusat & $13,07 \%$ & 100 \\
\hline .4 & 4 & DPRD DKI Jakarta & $10.20 \%$ & 78 \\
\hline .5 & 11 & Akademisi & $9,80 \%$ & 75 \\
\hline 6 & 10 & Masyarakat & $6,54 \%$ & 50 \\
\hline .7 & 7 & KPK & $6,41 \%$ & 49 \\
\hline .8 & 10 & Pengusaha & $5,36 \%$ & 41 \\
\hline .9 & 6 & Tenaga Hukum & $4,71 \%$ & 36 \\
\hline .10 & 5 & $\begin{array}{l}\text { Lembaga } \\
\text { Pemerintah (Non- } \\
\text { Pemerintah) Non- } \\
\text { Kementerian/ } \\
\text { Daerah }\end{array}$ & $4,31 \%$ & 33 \\
\hline .11 & 2 & DPR RI & $1,96 \%$ & 15 \\
\hline & & Jumlah & $100 \%$ & 765 \\
\hline
\end{tabular}

Tabel 3 diatas menunjukkan bahwa secara agregat terdapat kemunculan sebanyak 765 dari 11 narasumber. Artinya satu berita bisa memuat lebih dari satu narasumber.

Salah satu narasumber yang mendapat frekuensi kemunculan tinggi adalah pemerintah daerah. Dalam konteks ini, sosok Ahok sebagai Gubernur DKI Jakarta sering mendapat perhatian dari media massa untuk mengomentari proyek reklamasi. Hal ini karena proyek reklamasi memang berada dalam wilayah administrasi Provinsi DKI Jakarta. Maka sangat wajar jika Ahok ,sapaan Basuki Tjahaja Purnama, 
sering muncul dalam pemberitaan reklamasi. Munculnya Ahok sebagai Gubernur DKI Jakarta bukan hanya memberikan penjelasan terkait sengkarut proyek reklamasi, tetapi juga sering tampil dalam perdebatan pendapat melalui media massa dengan beberapa instansi terkait, seperti Pemerintah Pusat, DPRD DKI Jakarta, DPR RI, dan Lembaga Swadaya Masyarakat yang fokus pada isu lingkungan hidup.

Sebagai pihak yang kontra akan reklamasi, tentu LSM akan mendapatkan tempat untuk menyampaikan kontraargumentasinya. Ada beberapa LSM yang terlibat dalam perdebatan tentang isu Reklamasi Teluk Jakarta, yaitu Misalnya Wahana Lingkungan Hidup Indonesia (WALHI), Greenpeace, dan Koalisi Selamatkan Teluk Jakarta (KTSJ) yang terdiri dari beberapa kelompok LSM.

LSM bukan hanya melakukan kritik kepada Pemprov DKI Jakarta, tetapi juga kepada Pemerintah Pusat yang dinilai tidak serius dalam menangani kasus reklamasi. Bahkan dalam beberapa kesempatan, LSM dan masyarakat mendesak Presiden Joko Widodo untuk meneken Inpres (Instruksi Presiden) terkait penghentian reklamasi. ${ }^{16}$

Berada pada dua kutub yang berseberangan memang membuat pemerintah dan LSM sering terlibat perdebatan. Maka, tak jarang juga akademisi dimintai pendapatnya atas suatu permasalahan. Tak terkecuali persoalan reklamasi. Para pengamat tata kota dan ahli kelautan memberikan pandangannya terkait proyek triliunan ini. Mereka memediasi dua pandangan yang saling berseberangan dan kerap kali juga menyampaikan kritik.

Di lain sisi, pengusaha tidak banyak bicara soal reklamasi. Dalam beberapa pemberitaan, kelompok pengusaha hanya meminta pemerintah untuk memutuskan ke mana arah proyek reklamasi ini akan dibawa, dilanjutkan atau diberhentikan. Mereka hanya menunggu dan mengikuti

${ }^{16}$ Kahfi Dirga Cahaya“ „Presiden Jokowi Didesak Buat Inpres Terkait Moratorium Reklamasi, "https://nasional. kompas.com/read/2016/05/08/14053961/Presiden.Jokowi.Didesa regulasi dari pemerintah. Meski akhirnya kelompok pengusaha ini pun beradu argumen dengan kelompok kontrareklamasi pada persidangan di Pengadilan Tata Usaha Negara.

KPK dijadikan narasumber dalam pemberitaan reklamasi karena terkait kasus suap raperda yang menjerat anggota DPRD DKI Jakarta. Begitu juga dengan Tenaga Hukum, baik hakim, jaksa ,atau advokat karena terkait dengan gugatan LSM dan masyarakat umum pada sidang penghentian reklamasi di Pengadilan Tata Usaha Negara. Demikian juga dengan DPR RI, terlibat hanya beberapa kali saja pada saat pemanggilan menteri dan para pemimpin daerah yang terlibat kasus reklamasi ke gedung MPR/DPR RI .

\section{Sebaran Kritik pada Beragam Pihak Dalam Pemberitaan Reklamasi Teluk Jakarta di Kompas.com Tahun 2016}

Dalam peliputan reklamasi, kompas.com tidak hanya melakukan pemaparan fakta saja. Tetapi juga melakukan kritik, baik dari insan pers itu sendiri ataupun menyampaikan kritikan dari orang yang memiliki kapasitas pada bidangnya.

Kritik yang dimuat dalam Kompas.com paling banyak ditujukan untuk tiga kelompok, yaitu Pemerintah Daerah, Pemerintah Pusat, dan Pengusaha/ Pengembang. Ketiga kelompok inilah yang terlibat langsung dalam proses reklamasi, baik dari segi teknis maupun yuridis. Bahkan kritikan-kritikan tersebut berujung pada aksi hukum, seperti yang dilakukan LSM kepada Pemprov DKI Jakarta.

Berdasarkan data yang peneliti olah, lebih dari 50\% kritikan ditujukan untuk para stakeholder, baik pusat atau pun daerah. Kritikan ini muncul dari mulai dari isu lingkungan, kasus suap, bertele-telenya perdebatan yang terjadi antara pusat dan daerah hingga isu ketimpangan sosio-

k.Buat.Inpres.Terkait.Moratorium.Reklamasi.(diakses pada 13 Maret 2019, pukul 12.39 WIB) 
ekonomi yang menimpa masyarakat nelayan.

Tabel 4. Sebaran Frekuensi tentang Pihak yang memperoleh kritik dari Kompas.com terkait Isu Reklamasi Teluk Jakarta

\begin{tabular}{|c|c|c|c|c|}
\hline $\begin{array}{l}\text { No. } \\
\text { Urut }\end{array}$ & No. & Kelompok & Persentase & Frekuensi \\
\hline .1 & 3 & Pemerintah Daerah & $34,57 \%$ & 223 \\
\hline .2 & 1 & Pemerintah Pusat & $22,48 \%$ & 145 \\
\hline .3 & 10 & Pengusaha & $16,74 \%$ & 108 \\
\hline .4 & 4 & DPRD DKI Jakarta & $7,13 \%$ & 46 \\
\hline .5 & 8 & $\begin{array}{l}\text { Lembaga Swadaya } \\
\text { Masyarakat }\end{array}$ & $6,82 \%$ & 44 \\
\hline 6 & 9 & Masyarakat & $6,51 \%$ & 42 \\
\hline .7 & 5 & $\begin{array}{l}\text { Lembaga Pemerintah } \\
\text { (Non-Pemerintah) } \\
\text { Non-Kementerian/ } \\
\text { Daerah }\end{array}$ & $1,55 \%$ & 10 \\
\hline .8 & 6 & Tenaga Hukum & $1,40 \%$ & 9 \\
\hline .9 & 11 & Akademisi & $1,24 \%$ & 8 \\
\hline .10 & 2 & DPR RI & $0,93 \%$ & 6 \\
\hline .11 & 7 & KPK & $0,62 \%$ & 4 \\
\hline \multicolumn{3}{|r|}{ Jumlah } & $100 \%$ & 645 \\
\hline
\end{tabular}

\section{Penyebutan Dampak Reklamasi yang Muncul dalam Pemberitaan Reklamasi Teluk Jakarta di Kompas.com tahun 2016}

Hasil analisis teks menunjukkan ada tiga dampak yang mengemuka akibat proyek ini, yaitu dampak ekologis, dampak ekonomis, dan dampak sosiologis Dampak ekologis terhitung ada 127 kemunculan dalam pemberitaan reklamasi. Dampak lingkungan yang ditampilkan di antaranya adalah kerusakan terumbu karang, sedimentasi, hancurnya habitat ikan dan menurunnya populasi ikan di sekitar lokasi proyek. Hal inilah yang menjadi salah satu dasar bagi aktivis dan LSM yang fokus pada isu lingkungan melakukan kritik kepada pemerintah, baik daerah maupun pusat .

Dampak sosial dan ekonomi juga diangkat oleh kompas.com dalam pemberitaannya. Masing-masing muncul dengan frekuensi sebanyak 117 dan 114 kemunculan dalam berita. Kesamaan konteks sosial dan ekonomi membuat kemunculannya hampir bersamaan. Jika pemberitaan menyebut dampak sosial, hampir selalu dampak ekonomi pun ikut disertakan. Penjelasannya tampak pada tabel 5 dibawah ini :

Tabel 5. Frekuensi Isu terkait Dampak Reklamasi Teluk Jakarta di Kompas.com pada tahun 2016.

\begin{tabular}{|c|l|c|c|}
\hline No. & Penyebutan Dampak & Persentase & Frekuensi \\
\hline .1 & Dampak Ekologis & $35,47 \%$ & 127 \\
\hline .2 & Dampak Ekonomis & $31,84 \%$ & 114 \\
\hline .3 & Dampak Sosiologis & $32,68 \%$ & 117 \\
\hline
\end{tabular}

\section{Kategori Isu Dominan dalam Pemberitaan Reklamasi Teluk Jakarta di .Kompas.com pada tahun 2016}

Terdapat 12 kategori isu yang muncul terkait isu reklamasi teluk Jakarta selama tahun 2016. Terhitung ada 6401 paragraf dari 589 berita. Hasil analisis teks menunjukkan bahwa kategori yang paling banyak muncul adalah kategori legal-formal perundang-undangan sebanyak 1641 paragraf atau $25,64 \%$ dari total 6401 paragraf. Isu peraturan perundang-undangan ini terkait erat dengan Rancangan Peraturan Daerah tentang Zonasi Wilayah Pesisir dan Pulau-pulau Kecil (ZWP3K), Keppres No. 52 Tahun 1995 tentang Reklamasi Pantai Utara Jakarta ,dan gugatan masyarakat nelayan terhadap SK Gubernur tentang reklamasi.

Dalam perumusan peraturan dan kebijakan publik apalagi yang terkait dengan bisnis tak jarang ada kepentingankepentingan pribadi atau golongan yang ikut serta di dalamnya. Dan tak jarang juga kepentingan-kepentingan ini menyebabkan tindakan melawan hukum seperti korupsi. Termasuk dalam proyek reklamasi ini, KPK menetapkan Sanusi dan Arisman Widjaja sebagai tersangka kasus suap raperda reklamasi. Masing-masing sebagai anggota DPRD DKI Jakarta dan Presiden Direktur PT. Agung Podomoro Land. Isu terkait korupsi reklamasi ini menempati posisi kedua setelah isu peraturan reklamasi 
dengan angka 1197 paragraf atau mencapai $18,70 \%$ dari total 6401 paragraf.

Tabel 6. Frekuensi Kemunculan Kategori Isu dalam Pemberitaan Reklamasi Teluk Jakarta di Kompas.com pada tahun 2016.

\begin{tabular}{|c|c|c|c|c|}
\hline No. & Kategori & Isu & Persentase & Frekuensi \\
\hline .1 & $\begin{array}{c}\text { Kategori } \\
9\end{array}$ & $\begin{array}{l}\text { Peraturan } \\
\text { perundang- } \\
\text { undangan yang } \\
\text { berkaitan dengan } \\
\text { reklamasi }\end{array}$ & $25,64 \%$ & $\begin{array}{c}1641 \\
\text { paragraf }\end{array}$ \\
\hline .2 & $\begin{array}{c}\text { Kategori } \\
6\end{array}$ & $\begin{array}{l}\text { Tindakan } \\
\text { melawan hukum } \\
\text { dalam perumusan } \\
\text { kebijakan } \\
\text { reklamasi Pantai } \\
\text { Utara Jakarta }\end{array}$ & $18,70 \%$ & $\begin{array}{c}1197 \\
\text { paragraf }\end{array}$ \\
\hline .3 & $\begin{array}{c}\text { Kategori } \\
4\end{array}$ & $\begin{array}{l}\text { Konflik vertikal } \\
\text { Pemerintah dan } \\
\text { Masyarakat }\end{array}$ & $11,40 \%$ & $\begin{array}{c}730 \\
\text { paragraf }\end{array}$ \\
\hline .4 & $\begin{array}{c}\text { Kategori } \\
10\end{array}$ & $\begin{array}{l}\text { Kepentingan } \\
\text { Bisnis dan } \\
\text { Pembangunan }\end{array}$ & $9,69 \%$ & $\begin{array}{c}620 \\
\text { paragraf }\end{array}$ \\
\hline .5 & $\begin{array}{c}\text { Kategori } \\
8\end{array}$ & $\begin{array}{l}\text { Mediasi } \\
\text { akademisi terkait } \\
\text { dampak dan } \\
\text { kebijakan } \\
\text { reklamasi Teluk } \\
\text { Jakarta. }\end{array}$ & $8,05 \%$ & $\begin{array}{c}515 \\
\text { paragraf }\end{array}$ \\
\hline .6 & $\begin{array}{c}\text { Kategori } \\
3\end{array}$ & $\begin{array}{l}\text { Konflik Vertikal } \\
\text { Gubernur DKI } \\
\text { Jakarta dan } \\
\text { Pemerintah Pusat } \\
\text { terkait kebijakan } \\
\text { reklamasi. }\end{array}$ & $7,92 \%$ & $\begin{array}{c}507 \\
\text { paragraf }\end{array}$ \\
\hline .7 & $\begin{array}{c}\text { Kategori } \\
11\end{array}$ & $\begin{array}{l}\text { Advokasi } \\
\text { Dampak, } \\
\text { Pelestarian, dan } \\
\text { Konservasi } \\
\text { Lingkungan. }\end{array}$ & $5,20 \%$ & $\begin{array}{c}333 \\
\text { paragraf }\end{array}$ \\
\hline .8 & $\begin{array}{c}\text { Kategori } \\
7\end{array}$ & $\begin{array}{l}\text { Dampak sosio- } \\
\text { ekonomi yang } \\
\text { muncul akibat } \\
\text { reklamasi Teluk } \\
\text { Jakarta. }\end{array}$ & $4,64 \%$ & $\begin{array}{c}297 \\
\text { paragraf }\end{array}$ \\
\hline .9 & $\begin{array}{c}\text { Kategori } \\
1\end{array}$ & $\begin{array}{l}\text { Pilkada DKI } \\
\text { Jakarta. }\end{array}$ & $3,14 \%$ & $\begin{array}{c}201 \\
\text { paragraf }\end{array}$ \\
\hline .10 & $\begin{array}{c}\text { Kategori } \\
2\end{array}$ & $\begin{array}{l}\text { Konflik } \\
\text { Horizontal DPRD } \\
\text { DKI Jakarta dan } \\
\text { Gubernur DKI } \\
\text { Jakarta terkait } \\
\text { kebijakan } \\
\text { reklamasi. }\end{array}$ & $2,09 \%$ & $\begin{array}{c}134 \\
\text { paragraf }\end{array}$ \\
\hline .11 & $\begin{array}{c}\text { Kategori } \\
12\end{array}$ & DLL & $2,08 \%$ & $\begin{array}{c}133 \\
\text { paragraf }\end{array}$ \\
\hline
\end{tabular}

\begin{tabular}{|c|c|l|c|c|}
\hline .12 & $\begin{array}{c}\text { Kategori } \\
5\end{array}$ & $\begin{array}{l}\text { Konflik } \\
\text { horizontal antar } \\
\text { Masyarakat }\end{array}$ & $1.45 \%$ & $\begin{array}{c}93 \\
\text { paragraf }\end{array}$ \\
\hline \multicolumn{2}{|r|}{ Jumlah } & $100 \%$ & $\begin{array}{c}6401 \\
\text { paragraf }\end{array}$ \\
\hline
\end{tabular}

Tabel 6 menunjukkan bahwa kategori isu tentang hukum perundangan merupakan kategori yang paling banyak muncul atau paling dominan. Kategori berikutnya yang banyak muncul masih juga terkait hukum, namun lebih pada tindakan mewalan hukum dalam perumusan kebijakan reklamasi. Isu ini muncul sebanyak $18.6 \%$ atau sebanyak 1197 paragraf. Tindakan ini kemudian memunculkan dugaan kasus korupsi dalam proyek reklamasi yang membuat aktivisaktivis anti korupsi dan lingkungan menjadi lebih geram. Inilah mengapa kategori 4 yaitu konflik antara pemerintah dan masyarakat juga memperoleh frekuensi kemunculan cukup tinggi, yaitu sebanyak $11,4 \%$ atau 730 paragraf. Dengan demikian, tiga isu yang masuk dalam tiga kategori isu terbanyak dibicarakan dalam pemberitaan reklamasi teluk Jakarta berkaitan dengan aspek hukum perundangan, tindakan melawan hukum dan konflik antara pemerintah dan masyarakat.

Kategori lainnya, seperti kepentingan bisnis dan pembangunan muncul sebanyak $9,69 \%$ atau 620 paragraf dari 6401 paragraf ,515 paragraf yang berisi saran dari pakar dan akademisi,7,92\% atau 507 paragraf yang memuat konflik antara Pemprov DKI Jakarta dan Pemerintah Pusat, persoalan lingkungan yang krusial karena menyangkut kehidupan biota laut, terlebih lagi menyangkut kehidupan masyarakat nelayan hanya muncul dengan frekuensi sebanyak 333 paragraf atau 5,20\%, dampak sosio-ekonomi dengan frekuensi kemunculan sebanyak 297 paragraf atau $4,64 \%$ dari seluruh paragraf. Padahal dampak ini sangat terasa bagi masyarakat nelayan yang bekerja pada sektor informal.

Isu Pilkada DKI Jakarta ternyata tidak terlalu signifikan dalam kemunculan frekuensinya. Meski tahun 2017 adalah 
tahun politik, di mana Pemilihan Gubernur di DKI Jakarta akan dilangsungkan, hanya ada 201 paragraf atau 3,14\% yang termasuk dalam kategori ini. Kemungkinan tahun 2016 bukanlah masa kampanye, sehingga persoalan reklamasi hanya ada di penghujung tahun saja dan tidak terlalu mengemuka dalam pemberitaan.

Kisruh antara Gubernur DKI Jakarta dan DPRD dalam raperda reklamasi pun tidak signifikan setelah penangkapan Sanusi oleh KPK. Kisruh ini diakibatkan karena Ahok sebagai Gubernur DKI Jakarta saat itu menulis kata" Gila "dalam raperda reklamasi. Karena Ahok tidak setuju dengan usulan DPRD soal besaran kontribusi tambahan bagi pengembang. Frekuensi kemunculan kategori ini hanya tercatat sebanyak 134 paragraf saja atau 2,09\% dari total seluruh paragraf.Untuk kategori isu tentang konflik horizontal masyarakat muncul sebanyak 93 paragraf atau $1,45 \%$ dari 6401 paragraf.

\section{Diskusi dan Interpretasi}

Hasil penelitian ini menunjukkan bahwa fungsi informasi menjadi fungsi yang paling dominan dalam cara media memberitakan isu reklamasi teluk Jakarta. Bisa dikatakan fungsi ini menjadi dominan karena fungsi utama produk jurnalistik yaitu menyampaikan informasi. Demikian juga dalam praktik jurnalisme lingkungan. Hal ini dikatakan oleh Al Gore (dalam Rademakers) bahwa fungsi jurnalisme lingkungan hidup adalah memberikan informasi sekaligus mengedukasi masyarakat terkait kesadaran lingkungan hidup. ${ }^{17}$ yaitu sejauhmana media mampu membangkitkan dan menyadarkan masyarakat luas tentang kondisi lingkungan hidup mereka.

Hasil penelitian ini juga menunjukkan kompas.com cenderung secara dominan menyajikan pemberitaan dalam satu sisi, yaitu mengarah pada satu

${ }^{17}$ Lisa Rademakers, $A$ Theses of Examining The Handbooks On Enviromental Journalism: A Qualitative Document Analysis and Response to The Literature, h.8. arah opini yang seragam meski menggunakan lebih dari narasumber. Jika merujuk ke Rademakers, kesadaran lingkungan hanya bisa dicapai jika media massa menyajikan isu lingkungan dari berbagai sisi dalam satu artikel beritanya. Rademakers melihat isu lingkungan hidup terlalu kompleks, sehingga harus melibatkan banyak pihak. Di antaranya adalah ekonomi, politik, hukum, sosial, dan lingkungan hidup itu sendiri. ${ }^{18}$ Itulah mengapa Gregory mengatakan media harus membantu publik membangun persepsi tentang lingkungan hidup dengan cara menampilkan dua pandangan dalam pemberitaannya. ${ }^{19}$

Pengukuran pola penyajian berita diukur berdasarkan pandangan atau opini yang dikemukakan oleh sumber berita dari pada tokoh itu sendiri. Artinya penonjolan berita lebih ditekankan pada bagaimana pendapat tokoh, bukan pada siapa sosok tokoh tersebut. Dengan demikian, meskipun dalam satu berita terdapat tiga narasumber dengan latar belakang yang berbeda, akan dilihat sebagai satu pandangan jika memiliki cara dan sudut pandang yang sama.

Dari data yang peneliti olah, Kompas.com lebih dari $75 \%$ berita hanya menyajikan satu sisi pandangan saja . Penyajian berita dengan dua sisi pandangan hanya mendapat porsi yang sedikit sekali jika dibandingkan dengan penyajian satu sisi, yakni hanya $18,51 \%$. Padahal seperti yang dikatakan oleh Gregory, penyajian dua sisi pandangan membantu pembaca mendapatkan informasi yang lebih lengkap bahkan lebih luas akan satu isu.

Dengan mengakomodasi dua pandangan, media juga bisa menampilkan analisis mengenai untung rugi dari satu kebijakan publik. Menurut Abrar, dengan menampilkan keuntungan dan kerugian tersebut, publik bisa mempertanyakan seberapa besar keuntungan yang didapat oleh masyarakat dari proyek tersebut dan berapa banyak kerugian yang akan

\footnotetext{
${ }^{18}$ Lisa Rademakers, $A$ Theses of Examining The Handbooks On Enviromental Journalism: A Qualitative Document Analysis and Response to The Literature, h.15.

${ }^{19}$ R .Gregory, Risky Business: Communicating Issues of Science, Risk, and Public Policy, h. 2.
} 
ditanggung oleh mayarakat dan lingkungan? ${ }^{20}$

Selain itu, model penyajian yang melibatkan lebih dari satu pandangan juga memungkinkan terjadinya mediasi di antara para pengambil kebijakan dengan kelompok-kelompok yang dinilai rentan akan dampak reklamasi. Tetapi sama seperti model penyajian dua sisi, model penyajian multi sisi hanya mendapatkan porsi sebanyak 3,05\% dari total 589 berita.

Temuan ini diasumsikan karena media massa daring/online memiliki pola separasi, yakni memecah suatu informasi menjadi beberapa berita. Misalnya, informasi dari narasumber A tidak digabungkan dengan informasi dari narasumber $\mathrm{B}$, melainkan dipecah menjadi dua berita yang berbeda. Bahkan tidak jarang informasi dari narasumber yang sama dibuat menjadi beberapa berita, karena redaksi menilai informasi tersebut akan terlalu panjang jika dimasukkan dalam satu artikel berita. Hal ini berbeda dengan media massa berbasis cetak yang memasukkan dua sisi atau lebih dalam pemberitaannya.

Yang menarik adalah narasumber yang paling banyak diambil pandangan terkait reklamasi adalah pemerintah daerah, khususnya Pemda DKI Jakarta. Bahwa pemerintah daerah sebagai pihak yang paling berwenang dalam kebijakan reklamasi adalah benar, tetapi media masa juga perlu untuk memberikan tempat secara proporsional bagi pihak-pihak lain yang terlibat. Misalnya saja masyarakat, dalam hal ini masyarakat nelayan, yang terdampak dari proyek reklamasi. Mereka hanya mendapat ruang sebesar $6,54 \%$ saja dari keseluruhan berita.

Media perlu memberi porsi seimbang bagi masyarakat yang terdampak. Alasannya adalah agar informasi didapat dari sumber pertama, pelaku atau aktor yang mengalami dampak dari reklamasi langsung, bukan diwakili oleh pandangan orang lain yang mungkin berbeda dengan pengalaman pihak masyarakat yang terdampak. Tampaknya selama ini masyarakat hanya dijadikan penonton atas keributan yang terjadi di antara pemangku kebijakan. Media harus jeli dalam melihat persoalan ini. Sehingga masyarakat bisa ikut terlibat sebagai subjek aktif dalam perkembangan isu lingkungan.

Begitu juga dengan narasumber dari kelompok pengusaha. Selama ini memang para pengusaha tidak ingin banyak komentar terhadap persoalan sengketa dalam perizinan proyek reklamasi. Apalagi setelah Presiden Direktur PT. Agung Podomoro Land, Arisman Widjaja, tersangkut kasus korupsi yang menyebabkan dirinya ditangkap oleh KPK. Pengusaha muncul dalam pemberitaan hanya sebatas memberikan klarifikasi saja, baik dalam kasus korupsi atau tuduhan pemalsuan tanda tangan nelayan, dan bersikap menunggu keputusan pemerintah tanpa banyak komentar. Sehingga, dengan sikap seperti itu, kemunculan pengusaha sebagai narasumber tidak banyak dalam pemberitaan.

Selain Pemerintah Daerah, kelompok yang paling dominan muncul sebagai narasumber adalah Pemerintah Pusat dan Lembaga Swadaya Masyarakat. Masingmasing muncul dengan angka di atas 100 kemunculan. Konflik sesama pengambil kebijakan dan konflik dengan pengawas kebijakan seperti LSM menjadi alasan intensnya frekuensi kemunculan narasumber kelompok-kelompok tersebut. Meskipun isu yang diangkat bisa karena persoalan regulasi atau pun karena egosektoral masing-masing institusi .

Sama seperti media massa, akademisi yang berfungsi sebagai mediator pun tidak memperoleh ruang yang banyak dalam pemberitaan. Rademakers menegaskan bahwa mencari pandangan dari narasumber yang berasal dari kelompok akademisi dan pakar merupakan salah satu cara untuk menjawab tantangan dari jurnalisme 
lingkungan hidup. ${ }^{21}$ Dari para pakar ini, jurnalis sebetulnya bisa meminta penjelasan dan interpretasi terhadap polemik reklamasi, bahkan yang berkemungkinan terhubung dengan kondisi ekonomi, sosial maupun politik. Terlebih lagi Hannigan berpendapat bahwa lingkungan hidup selalu berkaitan erat dengan santis, sangat sulit memisahkan keduanya. $^{22}$ Dari hasil koding pada bab sebelumnya, akademisi hanya muncul dengan persentase $9,80 \%$.

Artinya media massa melalui jurnalisnya perlu meminta pandangan akademisi terutama dalam bidang sosio-ekonomi, teknokrat, atau pakar pembangunan kota sebagai sebuah upaya mediasi antar kelompok kepentingan. LaFollete mengatakan bahwa kebijakan dan rencana pembagunan didasarkan pada kemajuan kota dan kesejahteraan warganya. Tidak semata-mata atas kepentingan bisnis semata yang kemudian hanya akan menghasilkan konflik-konflik sosial di belakangnya. ${ }^{23}$

Nono Sampono, misalnya, dipandang sebagai orang yang memiliki kapasitas untuk berbicara soal reklamasi dengan alasan disertasinya mengangkat masalah reklamasi. Hal inilah yang menurut $M$. Taufik, Wakil Ketua DPRD DKI Jakarta, Nono Sampono layak diundang dalam Rapat Dengar Pendapat Rancangan Peraturan Daerah tentang Rencana Tata Ruang Kawasan Strategis Pantai (RTRKSP) Utara Jakarta. $^{24}$ Namun, kemudian diketahui bahwa ternyata Nono Sampono adalah Presiden Direktur PT. Kapuk Naga Indah, anak perusahaan Agung Sedayu Group. ${ }^{25}$

Memang selain Nono Sampono, pakar lain dari ITB dan IPB juga ikut berkomentar atas polemik reklamasi ini. Tetapi yang jadi persoalan adalah porsinya tidak cukup memadai dalam pemberitaan. Sehingga lagilagi yang mencuat ke permukaan adalah

${ }^{21}$ Lisa Rademakers, $A$ Theses of Examining The Handbooks On Enviromental Journalism: A Qualitative Document Analysis and Response to The Literature, h.76.

22 A. John Hannigan, Environmental Sociology; A Social Constructionist Perspective, h. 94

${ }^{23}$ LaFollette, Making Science Our Own: Public Images of Science, (Chicago: The University of Chicago Press, 1990), h. 4.

${ }^{24}$ Jessi Carina“ „M Taufik Sebut Nono Diundang Karena Disertasinya Soal Reklamasi,"https://megapolitan.kompas.com/ $\mathrm{read} / 2016 / 07 / 14 / 12201921 / \mathrm{m}$.taufik.sebut.nono.diundang.karena. perseteruan antara pemerintah daerah dan pemerintah pusat. Padahalkeragaman sumber ( diversity of sources) menjadi penting dalam membentuk ruang informasi dan persepsi dalam kepala publik. Kelengkapan informasi dan keluasan pandangan yang disajikan media massa membuat publik memiliki pertimbangan yang cukup untuk memutuskan sikapnya terhadap proyek reklamasi.

Kompas.com sebagaimana media lainnya, juga perlu melakukan fungsi supervisi. Supervisi atau pengawasan, memposisikan media berperan sebagai watchdog .Di negara-negara demokrasi seperti Amerika Serikat dan Indonesia, sudah seyogianya media massa menjadi agen pengawas terhadap gerak-gerik eksekutif, legislatif, dan yudikatif. Kebijakan yang sekiranya tidak masuk dalam akal publik, sudah barang tentu harus dikritisi .

Dalam menjalankan fungsi supervisi, menurut Rademakers, jurnalis lingkungan hidup harus berani menggunakan ethical framework/kerangka etis, bertanya dan menganalisis secara kritis, mengadvokasi korban atau kelompok terdampak, bahkan harus berpikir layaknya seorang saintis. ${ }^{26}$ Kompas.com sendiri dalam fungsi supervisinya memuat kritik yang datang baik dari insan pers itu sendiri maupun dari kalangan yang memiliki kapabilitas dalam bidang yang terkait. Kritikan ini juga ditujukan untuk kelompok-kelompok yang bukan hanya berstatus sebagai pengambil kebijakan, tetapi juga pada kelompok yang berstatus sebagai pengawas kebijakan .

Pemerintah Daerah, dalam hal ini DKI Jakarta ,mendapat kritikan paling banyak dengan frekuensi kemunculan mencapai $34,57 \%$ atau muncul di 223 berita. Tentu hal ini sangat wajar mengapa kemunculannya

disertasinya.soal.reklamasi (diakses pada 30 April 2019, pukul 15.39 WIB)

25 Jessi Carina“ ,Ahli Bidang Reklamasi Jarang, Alasan Taufik Anggap Nono Layak Diundang, ,'https://megapolitan. kompas.com/read/2016/07/14/14022551/ahli.bidang.reklamasi.jar ang.alasan.taufik.anggap.nono.layak.diundang (diakses pada 30 April 2019, pukul 15.56 WIB)

${ }^{26}$ Lisa Rademakers, $A$ Theses of Examining The Handbooks On Enviromental Journalism: A Qualitative Document Analysis and Response to The Literature, h.71. 
sangat banyak. Pemerintah sebagai pengambil kebijakan sudah sepatutnya diberikan kritik, karena kebijakan yang tidak berpihak pada kepentingan umum hanya akan menguntungkan pihak-pihak tertentu saja. Ketimpangan akan melanggengkan dirinya sendiri jika kritik tidak diberikan ruang untuk bertumbuh .

Dengan melancarkan kritik, media berfungsi sebagai teropong rakyat atas tindak-tanduk yang dilakukan oleh lembaga-lembaga negara, baik eksekutif, legislatif, maupun yudikatif. Menurut Munandar, media massa dalam negara demokrasi bukanlah benda mati atau hidup dalam ruang yang vakum sebagai alat propaganda. Media tumbuh dan bergerak bersama masyarakat yang juga bergerak, bertumbuh, dan berkembang. ${ }^{27}$

Selain Pemerintah Daerah, Pemerintah Pusat dan Pengusaha juga menjadi sasaran kritik. Meski jumlah kemunculan tidak sampai 200kali dalam pemberitaan namun menjadi kelompok dominan kedua dan ketiga sebagai objek kritikan.

Adalah wajar jika pemerintah dan pengusaha menjadi kelompok yang dominan sebagai objek kritik. Hal ini bukan berarti bahwa kelompok di luar lingkaran penguasa dan pengusaha tidak memiliki kekeliruan yang bisa dikritik. Ini lebih pada potensi penguasa memiliki Political Power yang tidak dimiliki oleh pengusaha. Begitu juga pengusaha memiliki Economical Power yang tidak dimiliki oleh penguasa. ${ }^{28}$ Kekuasaan ini sangat mungkin menghadirkan kepentingan yang mendorong relasi penguasa dan pengusaha secara transaksional dan rentan pada penyalahgunaan wewenang.

Riset ini juga menunjukkan kritik yang ditujukan untuk DPRD tidak mencapai $10 \%$, hanya berada pada persentase $7,13 \%$ atau muncul sebanyak 46 kali dalam pemberitaan. Padahal kita ketahui bahwa

27 Dedy, N. Hidayat., Effendi Gazali., dkk. Pers dalam Revolusi Mei; Runtuhnya Sebuah Hegemoni, (Jakarta: PT. Gramedia Pustaka Utama, 2000), h. 209.

${ }^{28}$ Fred Magdoff dan John Bellamy Foster, Lingkungan Hidup dan Kapitalisme; Sebuah Pengantar, (Tangerang Selatan: Marjin Kiri, 2018), h. 103. sebuah kebijakan lahir atas kolaborasi antara eksekutif dan legislatif .Riset ini menemukan dua perbedaan. Pertama, pihak eksekutif baik pada tingkat daerah maupun pada tingkat pusat, muncul sebagai pihak narasumber sekaligus memperoleh kritik karena lembaga eksekutif mengeluarkan perijinan. Sebaliknya, pemberitaan tentang pihak legislatif (DPRD) lebih pada isu Peraturan Perundang-undangan dan hukum.

Dari analisis isi atas kategorisasi isu dominan tampak bahwa pola pikir pengambil kebijakan di negeri tentang isu lingkungan masih dalam kerangka legalformal. Pola pikir etika-normatif-filosofis bukan kecenderungan utama. Dalam hal ini ketika isu lingkungan lebih banyak ditampilkan dalam aspek hukum dan tindakan melawan hukum, artinya isu lingkungan lebih dilihat sebagai perdebatan tentang aturan-aturan yang bersifat politis. Hal ini senada dengan apa yang dikatakan oleh Hannigan, selain mengedukasi masyarakat terkait lingkungan, media massa juga bisa mempengaruhi kebijakan lingkungan. Dia menegaskan kembali dengan mengatakan bahwa tanpa keterlibatan media massa, isu-isu lingkungan tidak akan pernah masuk dalam diskursus publik dan menjadi bagian dari politik kebijakan. ${ }^{29}$ Karena sejak Deklarasi Stockholm yang dihasilkan melalui Konferensi Lingkungan Hidup PBB pada tahun 1972, lingkungan hidup bukan lagi menjadi persaoalan-persoalan yang dikaji secara ilmiah saja, melainkan terangkat dan masuk ke dalam bidang politik. ${ }^{30}$

Isu lingkungan yang sudah masuk pada ruang politik menyebakan kategori isu peraturan perundang-undangan mendapatkan persentase paling besar dalam kemunculan isu reklamasi selama setahun. Sehingga kategori ini menjadi kategori dominan yang muncul dalam isu reklamasi. Kategori ini juga yang menyebabkan

\footnotetext{
29 A. John Hannigan, Environmental Sociology; A Social Constructionist Perspective, (London: Routledge 1995), h. 81.

${ }^{30}$ Emil Salim, Pembangunan Berwawasan Lingkungan, (Jakarta: LP3ES, 1986), h. ix.
} 
mengapa Pemerintah Daerah sebagai regulator proyek reklamasi muncul lebih banyak sebagai narasumber dibanding dengan narasumber lainnya.

Isu soal peraturan ini mencakup soal Rancangan Peraturan Daerah Rancangan Zonasi Wilayah Pesisir dan Pulau-pulau Kecil (RZWP3K), Peraturan Pemerintah tentang Wilayah Jakarta, Bogor, Depok, Tangerang, Bekasi, Puncak, dan Cianjur (Jabodetabekpunjur), dan Izin Gubernur DKI Jakarta pada proyek reklamasi Pantai Utara Jakarta, serta aturan pajak dan retribusi bagi daerah..

Yang menarik adalah kategori isu yang mempersoalkan kelangsungan ekosistem dan dampak sosial dari proyek reklamasi berada di posisi ketujuh dan kedelapan. Padahal isu ini penting untuk menahan laju pembangunan yang mengakibatkan kerusakan pada ekosistem. Dengan posisi kemunculan ke tujuh dan ke delapan, riset ini menunjukkan bahwa bagi media isu tentang kelangsungan ekossitem dan dampak dari reklamasi terhadap masyarakat tidak menjadi isu penting, atau bukan menjadi agenda media. Isu lingkungan perlu ditampilkan dengan memperhatikan konteks-konteks perdebatan sosio-ekonomi dan politik-ekologi sehingga masyarakat bisa memahami akan kekuatan yang mereka miliki untuk mempengaruhi kebijakan publik. $^{31}$

Kedua, memang wacana yang berkembang di tengah publik sedikit sekali yang bersinggungan dengan isu lingkungan. Masyarakat kita lebih tertarik dengan berita kriminal dibanding dengan dengan berita tercemarnya sungai, apalagi pelaku kriminalnya adalah seorang pejabat publik. Alhasil, Kompas.com mengangkat isu korupsi sebagai Extra-Ordinary Crime dalam kasus suap Raperda Reklamasi sebanyak 1197 paragraf atau 18,70\% dari 6401 paragraf. Kategori tindakan melawan

31 L. Wilkins, Shared Vulnerability: The Media and American Perceptions of The Bhopal Disaster, (New York: Greenwood Press, 1987), h. 154. hukum ini menjadi kategori dominan nomor urut dua.

Selain itu, penempatan akadmisi sebagai narasumber penting dalam pemberitaan isu ligkungan hidup. Dalam naskah akademik terdapat tiga landasan yang harus diperhatikan, yakni landasan filosofis, landasan sosiologis, dan landasan yuridis. Tiga landasan ini menjadi dasar dalam memberika kritik melalui saluran media massa, baik elektronik maupun cetak. Potret demikian menjadi sangat wajar dan galib dalam sebuah negara yang menganut demokrasi sebagai sistem kepolitikannya.

Penyangkalan atau peringatan dari akademisi ini, peneliti sebut dengan nomenklatur mediasi. Sangat sulit untuk tidak melibatkan akademisi dalam isu-isu lingkungan sebagai mediator di antara pihak-pihak yang berkepentingan. Bahkan menurut Hannigan, akademisi menempati posisi sebagai gate-keeper. ${ }^{32}$ Artinya, akademisi menjaga bahkan mengoreksi berbagai kebijakan yang dinilai akan merugikan manusia dan lingkungannya. Namun demikian hasil riset menunjukkan bahwa kategorisasi terkait dengan pandangan akademisi hanya memperoleh frekuensi kemunculan sebesar 8,05\% dari total keseluruhan 6401 paragraf dan memperoleh posisi kelima dalam urusan isu dominan, dalam posisi dominan kelima. Sama halnya dengan frekuensi kemunculan akademisi sebagai narasumber, juga berada pada posisi kelima dengan perolehan persentase $9,80 \%$ atau hanya muncul sebanyak 75 kali dalam pemberitaan selama satahun.

Dalam memberikan pendapat di media massa, para akademisi tentu saja terpolarisasi dalam pilihan-pilihan tersedia, yaitu pro dan kontra terhadap reklamasi. Kompas.com sejauh ini mengakomodasi dua pendapat tersebut dalam pemberitaanpemberitaannya yang terkait dengan reklamasi. Namun ada juga akademisi yang

32 A. John Hannigan, Environmental Sociology; A Social Constructionist Perspective, h. 94 
mendukung reklamasi karena sudah kadung dilaksanakan. Jika dibatalkan, iklim investasi akan buruk dan meradang. Meskipun tetap mengkritik pemerintah untuk terus memperhatikan dampak yang mungkin terjadi akibat proyek tersebut .

Seperti halnya kademisi yang tergabung dalam Ikatan Alumni Institut Teknologi Bandung lebih memilih menyetujui reklamasi jika ditempatkan sebagai pilihan terakhir setelah sebelumnya melakukan Urban Generation. ${ }^{33}$

Dampak sosiologis maupun ekonomi yang muncul akibat proyek reklamasi ini tidak begitu mendapat perhatian dalam pemberitaan di Kompas.com. Hanya terdapat $4,64 \%$ saja dari 6401 paragraf yang memunculkan dampak reklamasi. Artinya, Kompas.com menyinggung isu ini hanya dalam 297 paragraf saja. Padahal dampak dari adanya reklamasi ini sangat terasa bagi masyarakat pesisir yang umumnya berprofesi sebagai nelayan.

Sebagai contoh, nelayan yang terdampak reklamasi ini mengeluh karena hasil tangkapannya menurun, ditambah jarak tempuhnya menjadi semakin jauh, sehingga implikasinya biaya produksi pun menjadi semakin tinggi. Ini membuat nelayan menjadi semakin terhimpit; biaya produksi naik, tapi hasil malah menurun, berbanding terbalik. Kehidupan nelayan sudah sulit, bahkan jika tidak ada proyek reklamasi. Menurut Salim, pendapatan mereka sangat tergantung dari populasi tangkapan di laut dan cuaca yang bisa mengganggu mereka. ${ }^{34}$

Dengan tidak banyak mengangkat dampak sosio-ekonomis, seolah-olah persoalan reklamasi hanya menjadi persoalan legalitasnya saja. Persoalan yang hanya menyangkut soal peraturan perundang-undangan, dan sederet konflik yang terjadi antara pemerintah pusat dan

\footnotetext{
${ }^{33}$ Nibras Nada Nailufar“, Ikatan Alumni ITB: Reklamasi Pilihan Terakhir ,"https://megapolitan.kompas.com/read/2016/ 08/04/20395141/ikatan.alumni.itb.reklamasi.pilihan.terakhir(diak ses pada 30 April 2019, pukul 18.56 WIB).

${ }^{34}$ Emil Salim, Pembangunan Berwawasan Lingkungan, h. 210 .
}

pemerintah daerah yang saling mengklaim atas siapa yang berhak mengeluarkan izin proyek reklamasi. Padahal ada ratusan nelayan yang terganggu bahkan terancam kehidupan sosial dan ekonominya. Politik kebijakan yang ambisius dengan mengesampingkan limbah sosial, yakni pemiskinan bagi mereka yang terdampak. ${ }^{35}$

Selain itu, riset ini juga menunjukkan bahwa isu konflik terkait reklamasi muncul sebanyak 730 paragraf atau $11,40 \%$ dan menduduki peringkat ketiga kategori isu dominan. Ini mengindikasikan ada ketidaksetujuan antara masyarakat dengan pemerintah dalam proyek reklamasi.

Kepentingan bisnis dalam liputan Kompas mencapai angka 620 paragraf atau $9,69 \%$ dari total seluruh populasi. Dengan angka tersebut, isu ini berada di atas isu dampak sosial dan lingkungan .Padahal kepentingan bisnis yang egoistis akan menimbulkan dampak-dampak yang tidak diharapkan, yakni kerusakan ekosistem, polusi udara, air, tanah, hingga kesenjangan sosial dan pengangguran. Dampak ini bagi sebagian ekonom disebut sebagai eksternalitas, sebuah terma yang dipandang sebagai hal yang lumrah dalam pembangunan ekonomi. Tapi Magdoff dan Foster mengkritik atas apa yang disebut sebagai eksternalitas sebagai bentuk ketidak-bertanggungjawaban pengusaha atas usahanya. Yakni mengesampingkan semua itu lalu membebankannya pada masyarakat dan lingkungan. ${ }^{36}$

Secara konteks sosial, proyek reklamasi ini memanas menjelang Pemilihan Umum Kepala Daerah (Pemilukada) DKI Jakarta. Agaknya politisasi isu proyek ini untuk Pilkada sangat dimungkinkan untuk terjadi, minimal digunakan sebagai serangan oleh lawan politik petahana. Namun dalam data yang peneliti olah, dari 589 berita dan 6401 paragraf, kategori isu Pilkada hanya

\footnotetext{
35 A. Sonny Keraf, Filsafat Lingkungan Hidup: Alam sebagai Sebuah Sistem Kehidupan, h. 152

${ }^{36}$ Fred Magdoff dan John Bellamy Foster, Lingkungan Hidup dan Kapitalisme; Sebuah Pengantar, h. 40.
} 
mendapat frekuensi kemunculan sebesar $3,14 \%$ atau hanya sebanyak 201 paragraf saja. Ini artinya sejak awal, penolakan masyarakat terhadap proyek reklamasi bukan didasarkan pada pilihan-pilihan politik praktis yang tersedia dalam rangka Pemilihan Kepala Daerah. Akan tetapi jauh dari itu, masyarakat mendasarkan penolakannya tersebut pada politik kebijakan pemerintah yang dinilai akan merugikan mereka sebagai masyarakat.

\section{E. Kesimpulan}

Riset ini menunjukkan bahwa fungsi pemberitaan di media daring Kompas.Com yang paling dominan terkait isu reklamasi teluk Jakarta adalah fungsi infomasi dibandingkan fungsi mediasi dan supervisi. Artinya, Kompas.com cenderung memposisikan diri sebagai sumber informasi bagi publik untuk memperoleh pengetahuan tentang isu reklamasi, tampa terlibat dalam memberikan pengawasan dan kritik atau memediasi antara pihak yang berkonflik. Namun demikian, informasi yang dipaparkan dalam pemberitaan tidak didominasi oleh pengetahuan tentang edukasi, advokasi, dan konservasi lingkungan hidup.

Selain itu, Kompas.com cenderung menonjolkan model penyajian berita satu sisi dari pada model dua sisi atau multi sisi. Padahal model dua sisi, atau bahkan multi sisi akan membantu publik mendapatkan informasi lebih lengkap dan komprehensif dalam satu berita.

Kompas.com juga tidak banyak menghadirkan sumber dari masyarakat terdampak sebagai informan atau narasumber kutipan. Meskipun suara masyarakat dianggap sudah diwakilkan oleh Lembaga-Lembaga Swadaya Masyarakat (LSM), tetapi perlu bagi media massa untuk mengangkat suara mereka sebagai pihak yang mengalami langsung dampak reklamasi.

Hasil riset ini juga menunjukkan bahwa Isu Peraturan Perundanganundangan, baik itu Keppres, Permen, dan
Perda yang menjadi payung hukum dari proyek tersebut, menjadi isu yang paling dominan dimunculkan oleh Kompas.com . Kategori isu yang terkait dengan edukasi, advokasi, dan konservasi lingkungan hidup hanya hanya muncul sebanyak 5,20\% dari 6401 paragraf. 


\section{DAFTAR PUSTAKA}

Abrar, Ana Nadhya. 1993. Mengenal Jurnalisme Lingkungan Hidup. Yogyakarta: Gadjah Mada University Press.

2011 - Analisis Pers: Teori dan Praktik. Yogyakarta: Penerbit Cahaya Atma Pustaka.

Albert L. Hester, dan Wai Lan J.To. 1997. Pedoman Untuk Wartawan. Jakarta: Penerbit Yayasan Pustaka Obor Indonesia.

Ardial .2014 .Paradigma dan Model Penelitian Komunikasi. Jakarta:

Penerbit PT Bumi Aksara.

Atmakusumah, Maskun Iskandar, dan Warief Djajanto Basoeri, ed. 1996. Mengangkat Masalah Lingkungan ke Media Massa. Jakarta: Penerbit Yayasan Pustaka Obor Indonesia.

Baskoro, L.R. 2003. Jurnalime Lingkungan, Jurnalisme Menggerakkan. Jakarta: Penerbit Yayasan Karya Jurnalis Indonesia.

Birowo ,M. Antonius. 2004. Metode Penelitian Komunikasi. Yogyakarta: Penerbit Gitanyali.

Dewi ,Putri Aisyiyah Rachma. 2011. Jurnal Ilmu Sosial dan Ilmu Politik. "Analisis Pemberitaan Lingkungan Hidup di Media Massa Jawa Pos," Volume 12. Bulan November.

Eriyanto. 2011. Analisis Isi; Pengantar Metodologi Untuk Penelitian Ilmu Komunikasi dan Ilmu-Ilmu Sosial Lainnya. Edisi Pertama. Jakarta: Penerbit Kencana Prenada Media Group.

Frome. 1998. Green Ink: An Introduction to Environmental Journalism. Salt Lake City: University of Utah Press .

Gregory ,R. 1991. Risk perceptions as substance and symbol. In L. Wilkins and P.Patterson (Eds.). Risky Business: Communicating Issues of Science, Risk, and Public Policy. New York: Greenwood Press.

LaFollette, M. C. 1990. Making Science Our Own: Public Images of Science.
Chicago: The University of Chicago Press.

Handoyo, Eko. 2012. Kebijakan Publik. Semarang: Penerbit Widya Karya.

Hannigan, A. John. 1995. Environmental Sociology; A Social Constructionist Perspective. London: Routledge.

Hidayat, Dedy, N., Effendi Gazali., dkk. 20. Pers dalam Revolusi Mei; Runtuhnya Sebuah Hegemoni. Jakarta: PT. Gramedia Pustaka Utama.

Komisi Penyiaran Indonesia. 2013. Kedaulatan Frekuensi ;Regulasi

Penyiaran, Peran KPI dan Konvergensi Media. Jakarta: Penerbit Buku Kompas.

Krippendorff, Klaus. 1993. Analisis Isi; Pengantar Teori dan Metodologi. Jakarta :Penerbit PT Raja Grafindo Persada.

Kriyantono, Rachmat. 2007. Teknik Praktis Riset Komunikasi. Jakarta: Penerbit Kencana Prenada Media Group.

Kurniawan ,Eko. 2006“ .Studi analisis isi pemberitaan media massa tentang lingkungan hidup dan implikasinya terhadap kebijakan pengelolaan lingkungan di Kabupaten Bangka". Semarang: Universitas Diponegoro.

Kusumaningrat ,Hikmat, dan Purnama Kusumaningrat. 2006. Jurnalisik; Teori dan Praktik .Bandung: Penerbit PT Remaja Rosda Karya.

Magdoff, Fred., dan John Bellamy Foster. 2018. Lingkungan Hidup dan Kapitalisme; Sebuah Pengantar. Tangerang Selatan: Marjin Kiri.

Mufid, M. 2017. Al-Tahrir: Jurnal Pemikiran Islam. Rekonstruksi Fikih

Kelautan Berbasis Antropokosmis; Studi Kasus Reklamasi Teluk Jakarta.

Narawi, H. 1995. Metode Penelitian Bidang Sosial. Yogyakarta: Gadjah Mada University Press

Nasrullah, Rulli. 2017. Media Sosial: Perspektif Komunikasi, Budaya, dan Sosioteknologi, Bandung: Simbiosa Rekatama Media. 
Poerwandari, E. K. 2007 .Pendekatan Kualitatif untuk Penelitian Perilaku Manusia. Depok: Penerbit Perfecta.

Rachmadi ,F. 1990. Perbandingan Sistem Pers; Analisis Deskriptif Sistem Pers di Berbagai Negara. Jakarta: Penerbit Gramedia.

Rademakers, Lisa. 2004“ .Examining The Handbooks On Enviromental Journalism: A Qualitative Documen Analysis and Response to The Literature ".Theses, USA: University of South Florida.

Salim, Emil. 1986. Pembangunan Berwawasan Lingkungan. Jakarta: LP3ES.

Sampono, N, A Purbayanto, J Haluan, A Fauzi, B Wiryawan, dan M Pascasarjana .2012 .Jurnal Perikanan dan Kelautan; Dampak Reklamasi Teluk JakartaTerhadap Kegiatan Penangkapan Ikan di Teluk Jakarta, "Dampak Reklamasi Teluk Jakarta Terhadap Kegiatan Penangkapan Ikan di TelukJakarta".

Septian, Santana K. 2017. Jurnalisme Kontemporer. Kedua. Jakarta: Penerbit Yayasan Pustaka Obor Indonesia.

Siebert, Fred S. dan Wilbur Schramm. 1984. Four Theories of The Press; The Authoritarian, Libertarian, SocialResponsibility, and Soviet Communist Concepts of What The Press Should and Do. Chicago: University of Illinois.

Siregar, Ashadi. 2002 .Bagaimana Meliput dan Menulis Berita untuk Media Massa. Yogyakarta: Penerbit Kanisius.

Sudibyo, Agus. 2014. Prinsip Etis Jurnalisme Lingkungan. Jakarta: Penerbit Gramedia.

Sugiyono. 2011. Metode Penelitian Kuantitatif, Kualitatif, dan R\&D. Bandung:Penerbit Alfabeta.

Sumadiria, Haris. 2006. Jurnalistik Indonesia. Bandung: Penerbit Simbiosa Rekatam Media.
Tanzeh, Ahmad, dan Suyitno. 2006. DasarDasar Penelitian .Surabaya: Penerbit Lembaga Kajian Agama dan Filsafat.

Tebba, Sudirman. 2005. Jurnalistik Baru. Ciputat: Penerbit Kalam Indonesia.

Wilkins, L 1987. Shared Vulnerability: The Media and American Perceptions of The Bhopal Disaster. New Yor: Greenwood Press

Media Massa:

Alsadad Rudi“ „Ahok: Kok Nelayan Tidak Pernah Kritik Reklamasi KCN,"? http://megapolitan.kompas.com/read /2016/04/18/ 16411201/Ahok.Kok.Nelayan.Tidak .Pernah.Kritik.Reklamasi.KCN.

Arimbi Ramadhiani “ ,Tak Perlu Jadi Ahli Untuk Menilai Reklamasi Destruktif , " https://properti.kompas.com/read/20 16/05/13/231236021/.Tidak.Perlu.Ja di.Ahli.untuk.Menilai.Reklamasi.De struktif .

Dimas Jarot Bayu“,Walhi: Reklamasi dan Proyek Properti Penyebab Banjir Jakarta,",

https://properti.kompas.com/read/20 15/012/13/170000021/Walhi.Rekla masi.dan.Proyek.Properti.Penyebab. Banjir.Jakarta

Estu Suryowati“ ,Gara-gara Reklamasi Pulau G, Banyak Nelayan Alih Profesi Jadi Kuli Bangunan," https://money.kompas.com/read/201 6/05/22/145900926/garagara.reklam asi.pulau.g.banyak.nelayan.alih.prof esi.jadi.kuli.bangunan

Fidel Ali“" ,Pemerintah Diminta Pastikan Kelanjutan Proyek Reklamasi ," https://megapolitan.kompas.com/rea $\mathrm{d} / 2016 / 10 /$

27/20000831/pemerintah.diminta.pa stikan.kelanjutan.proyek.reklamasi.

Jessi Carina" ,M Taufik Sebut Nono Diundang Karena Disertasinya Soal Reklamasi ,"

https://megapolitan.kompas.com/rea $\mathrm{d} / 2016$

/07/14/12201921/m.taufik.sebut.non 
o.diundang.karena.disertasinya.soal. reklamasi

Jessi Carina" ,Ahli Bidang Reklamasi Jarang, Alasan Taufik Anggap Nono Layak Diundang, , https://megapolitan.kompas.com/rea d/2016/07/14/14022551/ahli.bidang. reklamasi.jarang.alasan.taufik.angga p.nono.layak.diundang.

Kahfi Dirga Cahaya" ,Presiden Jokowi Didesak Buat Inpres Terkait Moratorium Reklamasi, , https://nasional.kompas.com/read/ 2016/05/08/14053961/Presiden.Joko wi.Didesak.Buat.Inpres.Terkait.Mor atorium.Reklamasi.

Kurnia Sari Aziza“ „Ahok: Reklamasi Laut Diprotes, Reklamasi Sungai Kamu Enggak Protes," https://megapolitan.kompas.com/rea d/2016/03/03/15042081/Ahok.Rekla masi.Laut.Diprotes.Reklamasi.Sung ai.Kamu.Enggak.Protes.

Nibras Nada Nailufar" , Ikatan Alumni ITB: Reklamasi Pilihan Terakhir ,’ https://megapolitan.kompas.com/rea d/2016/08/04/

20395141/ikatan.alumni.itb.reklama si.pilihan.terakhir.

Robertus Belarminus “ ,Guru Besar IPB: Kalau Reklamasi Tak Diteruskan, Iklim Investasi Semakin Buruk ,' https://megapolitan.kompas.com/ $\mathrm{read} / 2016 / 04 / 23 / 17152541 / \mathrm{Guru}$.Be sar.IPB.Kalau.Reklamasi.Tak.Diteru skan.Iklim.Investasi.Semakin.Buruk 